\title{
НАУКА ОБ ИСПОЛЬЗОВАНИИ СПЕЦИАЛЬНЫХ ЗНАНИЙ (СУДЕБНАЯ ЭКСПЕРТОЛОГИЯ): ПОНЯТИЕ, СУЩНОСТЬ И СТРУКТУРА
}

\author{
Дьяконова О.Г. \\ Московский государственный юридический университет имени \\ О.Е. Кутафрина (МГЮА), \\ Москва, Россия.
}

Проведенное исследование правовой категории с использованием специальных знаний позволило сделать вывод о необходимости выделения укрупненного правового образования - макроинститута. Изучение и разработку теоретических положений и практических рекомендаций по использованию специальных знаний предлагается оптимально осуществлять в рамках науки - судебная экспертология. В представленной статье отражены отдельные результаты исследования по реализации правовых институтов судебной экспертизы, участия специалиста, а также экспертизы в иных видах юрисдикционной деятельности и ряда других, входящих в правовой макроинститут использования специальных знаний. Предложения, выработанные на основе экспертологического подхода вполне могут быть положены в основу реформирования законодательства о судебно-экспертной деятельности и участии специалиста в судопроизводстве и других видах юрисдикционной деятельности.

Ключевые слова: специальные знания, судебная экспертиза, участие специалиста, наука, судебная экспертология.

Введение.

Теория и практика использования специальных знаний в государствах-членах Евразийского экономического союза (ЕАЭС) и целого ряда других стран подтверждает существование двух фрорм (процессуальная и непроцессуальная) использования специальных знаний и множества видов в рамках этих форм. Видами использования специальных знаний в процессуальной фрорме выступают: судебная экспертиза - в различных видах судопроизводства; экспертиза - в налоговой, таможенной, нотариальной деятельности и исполнительном производстве; участие специалиста в следственных, судебных и иных процессуальных действиях, включая участие переводчика (сурдопереводчика) педагога и психолога; консультация (по иной терминологии - заключение) специалиста, в судопроизводствах, исполнительном производстве и нотариальной деятельности. Отнесение предварительных исследований по уголовным делам к той или иной форме до сих пор вызывает дискуссии [1]. К видам использования специальных знаний в непроцессуальной фрорме как правило относят медицинские и психиатрические освидетельствования; ревизии, инвентаризации, налоговые и аудиторские проверки; консультации специалиста.

Институты судебной экспертизы, участия специалиста и другие, объединенные в рамках деятельности по использованию специальных знаний, остро нуждаются в унифицированном правовом регулировании вне зависимости от вида судопроизводства и иных видов юрисдикционной деятельности, но с учетом их особенностей. Это подтверждается большинством

Адрес для корреспонденции: Дьяконова Оксана Гинадевна, доктор юридических наук, доцент кафедры судебных экспертиз Московского государственного юридического университета имени О.Е. Кутафина, Москва, Россия. 125993. Россия, Москва, Садовая-Кудринская ул., дом 9, e-mail: oxana_diakonova@mail.ru 
ученых, а также результатами проведенного нами анкетирования правоприменителей: следователей, судей, судебных экспертов. Развитие законодательства в сторону усложнения правового регулирования, появления новых правовых институтов, ввиду расширения общественных отношений, подлежащих нормативной регламентации, создает предпосылки для укрупнения правовых элементов. Такой процесс наблюдается во многих отраслях права, что обусловливает вывод о необходимости объединения правовых институтов в условную категорию - правовой макроинститут.

Противоречивое и неполное нормативное и правовое регулирование использования специальных знаний свидетельствует о необходимости определения науки, способной подвергнуть изучению компоненты этой деятельности, предложить эффективные способы устранения пробелов и проблем, возникающих при ее реализации.

\section{Материал и методы.}

Исследование проводилось в отношении использования специальных знаний в различных формах и видах в государствах-членах ЕАЭС. В основу проведенного исследования были положены труды российских и зарубежных ученых, посвященные изучению институтов судебной экспертизы и участия специалиста: Т.В. Аверьяновой, И.А. Алиева, Ф.Г. Аминева, А.А. Аубакировой, В.Д. Арсеньева, Р.С. Белкина, А.Р. Белкина, В.М. Быкова, С.Ф. Бычковой, А.И. Винберга, Т.С. Волчецкой, Е.И. Галяшиной, В.М. Галкина, А.В. Дулова, Е.А. Зайцевой, А.М. Зинина, Е.В. Ивановой, Е.П. Ищенко, Н.И. Клименко, Ю.Г. Корухова, А.В. Кудрявцевой, Л.В. Лазаревой, Н.П. Майлис, Т.Ф. Моисеевой, Г.Г. Омельянюка, Ю.К. Орлова, Е.Р. Россинской, С.С. Самищенко, М.Я. Сегая, С.А. Смирновой, Т.В. Толстухиной, Ш.Н. Хазиева, К.Н. Шакирова, Л.Г. Шапиро, С.А. Шейоера, А.Р. Шляхова, А.И. Усова, Н.П. Яблокова и других ученых. Научные работы Т.В. Аверьяновой, А.И. Винберга, Р.С. Белкина, С.Ф. Бычковой, А.М. Зинина, Ю.Г. Корухова, Н.П. Майлис, Т.Ф. Моисеевой, Е.Р. Россинской, С.А. Смирновой, К.Н. Шакирова, А.Р. Шляхова, А.А. Эйсмана и других ученых послужили основой для формирования и развития общей теории судебной экспертизы, постепенно выросшей в современную науку - судебную экспертологию.

Методологическая база исследования основывалась на универсальных диалектических положениях, позволяющих объективно рассматривать фрормы использования специальных знаний в процессуальной деятельности, судебно-экспертную деятельность (далее - СЭД) во взаимосвязи с видами юрисдикционной деятельности, в которых она воплощается, в их собственном поступательном развитии. В развитие этого использовались и другие методы: анализ и синтез, аналогия, дедукция и индукция, классификация, а также специальные методы познания: сравнительно-правовой, исторический, формально-юридический и системнофункциональный, позволившие провести проблемно-аналитическое сравнительно-правовое исследование.

\section{Обсуждение.}

\section{1. Использование специальных знаний как правовая категория.}

Использование (обобщенно - применение и использование) специальных знаний является специфической деятельностью с участием лиц, ведущих судопроизводство или иной 
юрисдикционный процесс в государства-членах ЕАЭС, привлекающих сведущих лиц (экспертов и специалистов) в целях получения информации, имеющей значение для осуществления их процессуальной функции, или оказания иной помощи в процессуальном порядке. Эта деятельность регулируется нормативными положениями, содержащимися практически во всех процессуальных кодифицированных законах и в ряде отраслевых законов ЕАЭС.

Совокупность этих нормативных положений составляет правовые институты, например институт судебной экспертизы, институт участия специалиста в процессуальных действиях, экспертизы в иной юрисдикционной деятельности и другие. Все вышеперечисленные правовые институты предлагается считать частью одного целого - макроинститута использования специальных знаний. Вопрос о делении правовых институтов на виды имеет существенное значение для определения групп общественных отношений, подвергающихся регулированию, выделения и обособления отрасли права, определения места того или иного правового института в структуре права. В настоящее время наблюдается процесс расширения правового регулирования ввиду появления новых общественных отношений, а также необходимости в более четком регулировании существующих в связи с их укрупнением. Законодательство с каждым годом усложняется, появляются новые правовые институты, в рамках которых субинституты «вырастают» до уровня институтов. В целях выстраивания логической структуры элемента права представляется возможным выделить новую правовую категорию на макроуровне - макроинститут. Макроинститут - сложная совокупность норм права, регулирующих тождественные, родственные правоотношения в рамках нескольких отраслей права, в состав которых входят как институты, так и субинституты. Данный термин обладает новизной, но функционирование тех или иных систем на макро- и микроуровнях достаточно давно входит в предмет исследования различных общественных наук - экономики, социологии. Кроме того, к вопросу о правовом регулировании на указанных уровнях тех или иных общественных отношений ученые обращаются все чаще.

Обоснованием вывода о том, что правовая категория «использование специальных знаний» является именно правовым макроинститутом, могут послужить следующие ее признаки: обособленность, полнота регулирования, взаимосвязь по предметно-функциональному признаку, регулирует конкретные правоотношения и является сложносоставной. Деятельность в рамках судопроизводства или иного юрисдикционного процесса осуществляется в особой процессуальной форме, с последовательным переходом из одной стадии в другую, в том числе при обращении к специалистам и экспертам. Анализируемый макроинститут автоматически приобретает такое свойство, но, поскольку реализуется в различных процессуальных отраслях, он носит и межпроцессуальный характер.

Макроинститут использования специальных знаний является комплексным по своему характеру - в зависимости от связи предмета регулируемых правоотношений с другими элементами системы права. Комплексность этой категории заключается в том, что регулированием охватываются схожие правоотношения в различных отраслях права, имеющих процессуальный или смешанный характер, таких как гражданский, арбитражный, уголовный процесс, административное право и процесс, нотариальное право, исполнительное производство и некоторых других. Кроме того, данный макроинститут является сложным образованием, поскольку в его состав входят институты и субинституты, такие как: институт правового статуса сведущего лица, в него включаются субинституты правового статуса эксперта и специалиста; 
институт судебной экспертизы, в который включаются субинституты различных видов экспертиз (первичной и повторной экспертизы, комиссионной, комплексной); институт допроса сведущего лица (эксперта и специалиста); институт участия специалиста и другие.

По сорере правового регулирования анализируемый макроинститут является специальным, поскольку его наличие позволяет обособить сфреру регулирования посредством установления специфических правоотношений. По функции макроинститут использования специальных знаний является регулятивным, поскольку в его основе лежат нормы, регулирующие частично правовой статус субъектов, нуждающихся в помощи сведущих лиц, и самих сведущих лиц, а также нормы, устанавливающие процедурный порядок реализации прав и обязанностей указанных лиц с целью выполнения функционального предназначения.

Четко выделила виды правоотношений, регулируемых институтом судебной экспертизы, Е.А. Зайцева, указав на следующие экспертно-процессуальные отношения: «а) между должностными лицами, государственными органами, назначившими экспертизу, осуществляющими уголовное производство по делу в досудебных и судебных стадиях, и экспертом; б) отношения, которые возникают и развиваются под контролем правоохранительного органа, между экспертом и участниками процесса, имеющими в деле самостоятельный правовой интерес, и другими участниками процесса (переводчиками, специалистами, свидетелями, потерпевшими); в) отношения между участниками процесса и правоохранительным органом, назначившим экспертизу, по поводу экспертизы; г) отношения между самим экспертом и руководителем экспертного учреждения, если экспертиза проводится в экспертном учреждении; д) отношения между членами экспертной комиссии» [2]. Поддерживая приведенную выше точку зрения Е.А. Зайцевой, считаем необходимым ее дополнить и выделить правоотношения, которые можно отнести к экспертно-процессуальным, хотя в настоящее время не нашедшими правового урегулирования, но остро нуждающимися в нем.

Можно выделить ряд правоотношений, регулируемых в рамках макроинститута использование специальных знаний. Это отношения между: 1) экспертом, являющимся сотрудником СЭО, и ее руководителем при назначении и производстве судебной экспертизы; 2) экспертом, не являющимся сотрудником СЭО, но привлекаемым к производству экспертизы в СЭО и ее руководителем при назначении и производстве судебной экспертизы; 3) лицом (органом), ведущим юрисдикционную деятельность, и экспертом; 4) экспертом и участниками процесса, заинтересованными в юридическом исходе дела, в связи с назначением и производством судебной экспертизы при участии и с разрешения лица, ведущего процесс; 5) экспертом и лицами, юридически заинтересованными в исходе дела (лицами, участвующими в деле), их представителями, защитником обвиняемого (подозреваемого, подсудимого) при частном обращении к эксперту для получения заключения (альтернативная экспертиза); 6) экспертом и лицом, осуществляющим принудительное исполнение судебных актов и актов иных органов в рамках исполнительного производства (например, экспертиза по оценке имущества в рамках исполнительного производства); 7) лицом, осуществляющим принудительное исполнение судебных актов и актов иных органов в рамках исполнительного производства, и участниками исполнительного производства по поводу проведения экспертизы; 8) экспертом и нотариусом в рамках осуществления последним нотариальных действий и обеспечения доказательств; 9) нотариусом и участниками нотариальных действий по поводу проведения экспертизы; 10) экспертом и уполномоченным должностным лицом таможенного органа при назначении и 
производстве экспертизы для разъяснения возникающих вопросов при совершении таможенных операций; 11) уполномоченным должностным лицом таможенного органа и участниками таможенной деятельности отношения по поводу проведения экспертизы; 12) экспертом и должностным лицом налогового органа при проведении экспертизы при осуществлении налогового контроля; 13) должностным лицом налогового органа и участниками налоговых действий по поводу проведения экспертизы.

Указанные виды правоотношений считаем возможным включить в структуру межотраслевого правового института экспертизы, который имеет общие концептуальные основы с правовым институтом судебной экспертизы. Выделение этих правоотношений оправдано ввиду необходимости унифрикации правового регулирования экспертизы в судопроизводстве и иных видах юрисдикционной деятельности, с учетом процессуальных особенностей. Последняя оговорка необходима, поскольку указанные правоотношения, кроме первой группы (пункты 1-5), осуществляются не в рамках судопроизводства, что накладывает отпечаток на их регламентацию, однако при всей специфике, природа этих правоотношений тождественна правоотношениям, возникающим в судопроизводстве при проведении экспертизы. Наличие общего и специфики в институтах судебной экспертизы и экспертизы в иных видах юрисдикционной деятельности позволяют констатировать необходимость использования единой основы правового регулирования, базирующейся на нормах единого для судопроизводства и иной юрисдикционной деятельности специального закона. Предлагается на уровне государствчленов ЕАЭС принять новый Модельный закон Евразийского экономического союза «О судебноэкспертной деятельности и экспертизе в иных видах юрисдикционной деятельности» [3]. На уровне Российской Федерации - «О судебно-экспертной деятельности и экспертизе в иных видах юрисдикционной деятельности в Российской Федерации», а в иных государствах-членах ЕАЭС - привести нормы специальных законов о судебной экспертизе в соответствие с положениями нового Модельного закона ЕАЭС о СЭД, либо принять закон на основе указанного.

Таким образом, правовые институты судебной экспертизы и экспертизы в иной юрисдикционной деятельности являются частью одного целого - макроинститута использования специальных знаний. Оба института регламентируют формы использования специальных знаний в соответствующей деятельности.

Представляется, следующие укрупненные виды правоотношений входят в институт участия специалиста, формируя отношения между: 1) должностными лицами, ведущими процесс (как судопроизводство, так и другие виды юрисдикционной деятельности, например, исполнительное производство), и привлекающими специалиста для участия в нем; 2) специалистом и лицами, юридически заинтересованными в исходе дела (лицами, участвующими в деле), их представителями, защитником обвиняемого (подозреваемого, подсудимого), в том числе в частном обращении к специалисту с целью получения консультации; 3) лицами, юридически заинтересованными в исходе дела, их представителями, защитником обвиняемого (подозреваемого, подсудимого) и должностными лицами, ведущими процесс, по поводу привлечения к участию в процессе специалиста.

Проведенный анализ [3] показывает, что макроинститут использования специальных знаний представляет собой совокупность правовых норм, регулирующих общественные отношения в сфрере использования специальных знаний в судопроизводстве и иной юрисдикционной деятельности государств-членов ЕАЭС, носящую межпрочессуальный, 
специальный и комплексный характер, выступающую в виде сложного правового образования, включающего процессуальные комплексные институты и субинституты.

Изучение правовых, процессуальных, методологических и организационных основ макроинститута использование специальных знаний и входящих в него институтов судебной экспертизы и правового статуса эксперта, участия специалиста и других выявило необходимость поиска ответа на вопрос - предметом исследования какой науки или области научного знания могут стать перечисленные институты. Это актуально для определения места формирующихся теоретических положений об институте судебной экспертизы в рамках предмета определенной отрасли науки, а также с учетом нормативно-правовой регламентации определения места положений, регулирующих указанный институт в системе права.

\section{2. Становление науки об использовании специальных знаний.}

Каждое структурное звено права, каждая отрасль, правовой институт являются предметом изучения той или иной науки. Именно разрабатываемые теоретические положения позволяют отраслям права, правовым институтам развиваться и совершенствоваться. Представляется, исследуемый макроинститут использования специальных знаний может быть предметом изучения нескольких наук, - при наличии основополагающей науки.

Научные знания о макроинституте использования специальных знаний еще находятся в процессе систематизации, причиной тому вполне может быть становление относительно молодой науки, которая является базовой для формирования положений правового макроинститута. Исследуемая наука в настоящее время не охватывает весь макроинститут использования специальных знаний, т.к. основная часть научных разработок посвящена в основном судебной экспертизе. В целом же макроинститут использования специальных знаний является предметом изучения нескольких наук: процессуальных (уголовно-процессуальной, гражданскопроцессуальной и т.п.), доказательственного права, исполнительного производства (как научной отрасли) и, собственно, основополагающей - судебной экспертологии.

Однако, ученые по-разному предлагали именовать эту науку: судебная экспертология (А.И. Винберг, Н.Т. Малаховская, Е.Р. Россинская, Е.И. Галяшина и др.) или общая теория судебной экспертизы (или теория судебной экспертизы - А.Р. Шляхов, Т.В. Аверьянова и др.). Авторов объединяет то, что в наименовании науки они, так или иначе, отражали предмет ее исследования - судебную экспертизу во всем многообразии представлений о ней.

Объясняя причину утверждения среди ученых именно термина «экспертология», а не «экспертоведение», «экспертика» или «экспертизоведение», «экспертизология» и т.д., Е.И. Галяшина пишет, «что термин «экспертология» как лексическая единица естественного языка обладает признаком языковой мотивированности. Мотивированность семантики и функции номинации «экспертология» как термина определяется прямым отношением к объекту обозначения - сфере научного знания о судебной экспертизе и местом термина в терминосистеме данной науки» [4]. В итоге она делает справедливый вывод, что «независимо от нашего желания или нежелания того, термин «экспертология» прочно вошел не только в речевой обиход, но и в систему языка экспертов» [4].

Конечно, любой из предложенных авторами термин имеет право на существование и способен в целом выразить ее сущность. Но, полагаем, что при определении наименования науки необходимо учитывать предмет ее исследования, а также цель одноименного обозначения 
учебной дисциплины, основанной на данной научной отрасли, в связи с чем, представляется наиболее верным использовать наименование «судебная экспертология». В этом мы солидарны с мнением Е.Р. Россинской, которая полагает, что данный термин в настоящее время больше соответствует реальному положению вещей [5,6].

Можно определить основные вехи развития научной мысли о судебной экспертизе, которые привели к формированию судебной экспертологии. Основоположниками теории судебной экспертизы условно можно считать П.И. Тарасова-Родионова и Ю.М. Кубицкого, а также других ученых, полагавших возможным становление самостоятельной науки о криминалистической экспертизе [7]. Позже А.И. Винберг подверг критике позицию этих ученых, но при этом указал на существование в рамках криминалистики общей теории криминалистической экспертизы [8]. Ряд ученых (М.М. Выдря, А.Р. Шляхов) отстаивали «идею об отделении теории криминалистической экспертизы от криминалистики в самостоятельную область научного знания» [9]. В последующем, вплоть до 1969 года, только А.Р. Шляхов отстаивал необходимость существования независимой и самостоятельной науки, с собственным предметом, объектом и методом, - криминалистической экспертизы, предложив, однако, включить в ее предмет помимо методов исследования доказательств, также методы их обнаружения и фиксации [10], что весьма расширяло содержание науки. Но и он в дальнейшем отказался от данной идеи. Большинство ученых не поддержало концепцию А.Р. Шляхова, обоснованно посчитав ее «с точки зрения содержания ее появление не давало ничего нового ни для теории, ни для практики борьбы с преступностью в целом» [11].

В 1973 году А.И. Винберг и Н.Т. Малаховская озвучили термин «судебная экспертология», в последующем проработав и опубликовав в 1979 учебное пособие [12]. Указанная работа послужила своеобразным толчком в развитии дискуссии о новой отрасли научного знания.

Авторы впервые представили концепцию новой науки - судебной экспертологии, в которую включили общетеоретические вопросы и общие положения «предметных наук» судебной химии, судебной фризики, судебной биологии, судебной медицины.

А.А. Эйсман в определенной степени поддержал данную идею, отметив, что «в общей части экспертологии следует рассматривать классификацию родов и видов экспертиз, задачи экспертной практики, фрункции экспертных учреждений, их организационную структуру, систематику методов экспертного исследования и теории выводов эксперта, роль которой может выполнять теория криминалистической идентификации, помимо этого учение о логической структуре вывода эксперта, теория оценки экспертом обнаруженных в ходе исследования данных, общие начала экспертных методик» [13]. Однако, он считал судебную экспертологию частью криминалистики.

Важнейшим разделом судебной экспертологии, по мнению А.И. Винберга и Н.Т. Малаховской, выступает сравнительное экспертоведение - «сравнительное изучение различных отраслей знаний в области судебных экспертиз для выявления присущих им общих законов, принципов, структурных связей (связи корреляционные, сосуществования, генетические и др.) и отношений, общности их происхождения в аспекте гомологии (сходства)» [12]. При этом неоднозначной представляется идея указанных ученых о выделении целого ряда предметных «экспертных наук», например, судебной химии. Как верно пишет Е.Р. Россинская, «формирование предметных судебных наук - исключение из общего правила, что подтверждает практика и дальнейшее развитие общей теории судебной экспертизы» [14]. Однако «сравнительное экспертоведение» 
на сегодняшний день актуально как никогда.

Таким образом, в 80-е годы прошлого века сложились предпосылки формирования и выделения науки о судебной экспертизе из рамок криминалистики. Позже многие авторы признавали, что раздел криминалистики, связанный с судебной экспертизой, уже не вписывается в предмет данной науки. Однако дискуссия о месте и соотношении науки о судебной экспертизе и других отраслей научного знания, по мнению некоторых ученых, еще не окончена.

Р.С. Белкин справедливо писал, что «судебная экспертология (или общая теория судебной экспертизы) имеет все основания для конституирования в самостоятельную область научного знания, если рассматривать ее как науку о закономерностях возникновения и развития судебных экспертиз, процесса экспертного исследования и фрормирования его результатов, закономерностей, проявляющихся в общности тех методологических и методических основ, на базе которых возможно объединение отдельных видов судебной экспертизы в единую целостную систему с четкой классификацией видов судебной экспертизы как ее элементов» [9]. И впоследствии вклад в развитие судебной экспертологии, как формирующейся отрасли научного знания, внесли Р.С. Белкин, И.А. Алиев, Т.В. Аверьянова, Ю.Г. Корухов, Н.П. Майлис, Т.Ф. Моисеева, С.Ф. Бычкова, К.Н. Шакиров и многие другие.

Правильно написала Т.В. Аверьянова, что «настоящее время - современный этап характеризуется становлением новой теории - науки о судебной экспертизе как самостоятельной области научного знания, которая призвана служить прочным фундаментом для формирования теоретических основ различных родов и видов экспертиз, и имеет синтетический характер с присущей интеграцией как юридических, так и естественно-технических наук» [15]. Отметим, что большинство ученых, посвящающих свои труды исследованию судебной экспертизы, а также выделяемого нами «макроинститута использования специальных знаний», поддерживают концепцию самостоятельной науки о судебной экспертизе - «судебной экспертологии».

\section{3. Предмет судебной экспертологии.}

Вышеназванными учеными, посвятившими свои труды теории судебной экспертизы, были созданы и разработаны принципиальные основы науки. Однако, далеко не всеми учеными признавалась возможность включения в предмет судебной экспертологии организационных и правовых начал СЭД.

Проведенный нами анализ [3] показал, что изучение организационных начал также необходимо включать в предмет судебной экспертологии. Во-первых, потому что качество СЭД в первую очередь зависит от организации ее осуществления в оптимальной форме. Во-вторых, подбор наиболее подходящей организационной формы экспертной организации оказывает непосредственное влияние на ее деятельность, способен как улучшить качество производства судебных экспертиз, так и свести его на нет. В-третьих, унификация как процесс постепенно должна охватить все сореры экспертной деятельности, от правовой, организационной до методической и сферы образования и повышения квалифрикации экспертов. Таким образом, именно в рамках судебной экспертологии созданы возможности улучшения качества подготовки и переподготовки экспертов, униорикации научно-методического обеспечения судебной экспертизы.

Обосновать необходимость включения правовых основ в предмет исследования судебной экспертологии можно следующим. Во-первых, судебная экспертология изучает общие 
закономерности, которые характеризуют судебную экспертизу, в том числе в процессе ее назначения и производства, во-вторых, эти закономерности неразрывно связаны с судопроизводством и иными видами юрисдикционной деятельности, что не позволяет сужать предмет исследования только уголовно-процессуальной сорерой, поскольку судебная экспертиза, как правовой институт, используется во всех видах судопроизводства, а также в исполнительном производстве, нотариальной, таможенной и иных юрисдикционных видах деятельности. По сути, сказанное обосновывает необходимость унификации правовых основ судебной экспертологии независимо от вида судопроизводства или юрисдикционной деятельности. Унификация правовых основ судебной экспертизы не может быть достигнута, если эти основы будут изучаться исключительно уголовно-процессуальным правом или какой-либо иной процессуальной наукой. Невозможно будет реализовать единые положения о судебной экспертизе на практике, что в настоящее время наглядно иллюстрируют действующие процессуальные кодексы ЕАЭС.

Профрессор Е.Р. Россинская предлагает следующее определение предмета судебной экспертологии: «предметом судебной экспертологии являются теоретические, правовые и организационные закономерности осуществления СЭД в целом; закономерности возникновения, формирования и развития классов, родов и видов судебных экспертиз и их частных теорий на основе единой методологии, унифицированного понятийного аппарата и с учетом постоянного обновления и видоизменения судебно-экспертных знаний и разрабатываемые на основе познания этих закономерностей единые для всех видов судопроизводства унифицированные экспертные технологии, стандарты экспертных компетенций и сертиорицированных экспертных лабораторий, единое правовое и организационное обеспечение СЭД» [6, 16]. Данное определение заслуживает поддержки, однако может быть дополнено включением теоретических, правовых и организационных закономерностей применения и использования специальных знаний в иных видах юрисдикционной деятельности (например, налоговой, таможенной, нотариальной, исполнительном производстве).

В правовые основы СЭД, изучаемые судебной экспертологией, в том числе при назначении и производстве экспертизы в иных видах юрисдикционной деятельности, можно включить:

- основы деятельности СЭО и правовой статус их руководителей;

- правовые основы правового и профессионального статуса судебного эксперта и эксперта, привлекаемого к производству экспертизы в иных видах юрисдикционной деятельности, как субъектов правоприменительной и правотворческой деятельности';

- правовые основы регламентации фрормальной и содержательной сторон результата деятельности эксперта - заключения судебной экспертизы или экспертизы в иных видах юрисдикционной деятельности, особенности его оценки и использования в различных видах юрисдикционной деятельности, включая судопроизводство;

- правовые основы международно-правового сотрудничества в области судебной экспертизы, экспертизы в иных видах юрисдикционной деятельности.

Полагаем также, что в рамках судебной экспертологии может быть отведено место изучению такой формы использования специальных знаний, как деятельность специалиста. Обосновывается

1 Правотворческая деятельность в этом контексте в широком смысле представляет собой деятельность компетентных лиц, направленную на создание, изменение, отмену правовых положений, принимаемых органами государственной власти Российской Федерации и ее субъектов, в целях совершенствования правового регулирования общественных отношений в той или иной сфере. 
такой подход, во-первых, общими основами использования специальных знаний в различных его фрормах в разных видах юрисдикционной деятельности, включая судопроизводство, необходимостью унификации деятельности специалиста в разных видах юрисдикционной деятельности, включая судопроизводство, при условии реализации им тождественных форм использования специальных знаний; во-вторых, наличием общих профессиональнокомпетентностных признаков эксперта и специалиста, в-третьих, неспособностью других наук, за исключением судебной экспертологии, обеспечить комплексный подход к изучению деятельности специалиста, что подчеркивается положениями действующего законодательства.

Аргументируя свое мнение, отметим, что, несмотря на существенные различия, специалиста и эксперта связывает многое. Изучение указанных вопросов позволит обобщить и унифицировать общие положения, касающиеся профрессионального статуса и подготовки сведущих лиц, конкретизировать различия между специалистом и экспертом, совершенствовать правовое регулирование в отношении обоих субъектов. Существуют и противоположные мнения. Многие ученые не считают нужным включать в предмет судебной экспертологии раздел «о специалисте», поскольку рассматривают его в рамках иных отраслей научного знания, например теории доказательств [17].

Учитывая изложенное, в предмет судебной экспертологии могут быть включены правовые основы:

- правового и профессионального статуса специалиста как субъекта правоприменительной и правотворческой деятельности;

- регламентации фрормальной и содержательной сторон результатов деятельности специалиста;

- консультации или заключения, а также особенности их использования в судопроизводстве и иных видах юрисдикционной деятельности.

Приведенные правовые основы могут быть объединены в один раздел - «правовое обеспечение применения и использования специальных знаний в юрисдикционной деятельности». Ранее мы писали о том, что следует выделить в отдельный раздел концептуальные основы деятельности специалиста. Но с учетом общих профессиональных основ деятельности сведущих лиц, форм использования специальных знаний, был сделан вывод о возможности исследования этих аспектов в рамках единого раздела [18,19]. Полагаем, что общие положения о фрормах использования специальных знаний в судопроизводстве и иных видах юрисдикционной деятельности должны быть включены в раздел «Концептуальные основы судебной экспертологии».

Следует отметить, что изучение вопросов о профессиональной деятельности, подготовке и повышении квалификации судебного эксперта, сертификации его деятельности и экспертной дидактики, включается нами в раздел «организационное обеспечение применения и использования специальных знаний».

Предложение включить указанные правовые основы в предмет судебной экспертологии вполне согласуется с наименованием этой науки, с учетом того, что в буквальном смысле - это учение о сведущем лице и деятельности, которую он осуществляет.

Указанные положения, включенные в предмет судебной экспертологии, не монополизируются исключительно этой наукой, они изучаются и рядом других наук, прежде всего, процессуальных. На наш взгляд такой подход способен обогатить научное знание и акцентирует необходимость 
совместных научных исследований в целях унификации правового регулирования. Фактически, судебная экспертология исследует закономерности осуществления той деятельности, которая связана с использованием специальных знаний, не посягая на предмет исследования процессуального права или доказательственного права, который находится во взаимосвязи с предметом судебной экспертологии.

\section{4. Структура судебной экспертологии.}

Анализ точек зрений ученых о предмете и структуре науки о судебной экспертизе позволяет выстроить структуру судебной экспертологии. Следует отметить, что в выделении большинства из указанных закономерностей и частных экспертных теорий, мы поддерживаем точку зрения Е.Р. Россинской $[6,16]$, но в определенной части ее можно дополнить и структурировать следующим образом [18]:

1) Концептуальные основы судебной экспертологии: 1.1 Учение о судебной экспертологии как науке: предмет, система, принципы, задачи, фрункции, методы судебной экспертологии; 1.2 Учение о формах использования специальных знаний в судопроизводстве и иных видах юрисдикционной деятельности; 1.3. Учение о сведущих лицах; 1.4 Учение о судебной экспертизе: предмет, объекты и их свойства и признаки, задачи судебной экспертизы; 1.5 Учение о закономерностях формирования и классификации судебных экспертиз по родам и видам; учение о закономерностях формирования и развития новых родов и видов судебных экспертиз; 1.6 Общие положения о СЭД, принципы СЭД, ее роль в судопроизводстве и иных видах юрисдикционной деятельности; 1.7 Учение о процессах, отношениях и целях экспертной деятельности: теория экспертной идентификации; теория экспертной диагностики; теория экспертного прогнозирования, теория экспертной реституции [20]; теория экспертной профилактики; 1.8 Учение о фрормах и средствах коммуникативной деятельности эксперта, включая взаимодействие со следователем, судом, руководителем экспертной организации, а также язык судебной экспертологии, система экспертных понятий, вопросы информатизации и формализации языка; 1.9 Общие теоретические положения частных теорий отдельных родов и видов судебных экспертиз (понятие частной экспертной теории, ее предмета, объектов, задач).

2) Правовое обеспечение применения и использования специальных знаний в юрисдикционной деятельности: 2.1 Правовая основа деятельности СЭО, правовой статус их руководителей'; 2.2 Основы правового и профессионального статуса судебного эксперта и эксперта, привлекаемого к производству экспертизы в иных видах юрисдикционной деятельности, как субъектов правоприменительной и правотворческой деятельности; 2.3 Учение об экспертной инициативе; 2.4 Правовые основы регламентации формальной и содержательной сторон результата деятельности эксперта - заключения судебной экспертизы или экспертизы в иных видах юрисдикционной деятельности, особенности его оценки и использования в различных видах юрисдикционной деятельности, включая судопроизводство; 2.5 Основы правового и профрессионального статуса специалиста как субъекта правоприменительной и правотворческой

\footnotetext{
Полагаем неприемлемым термин государственный»/«негосударственный» по отношению к экспертам, он относится к форме учреждения или организации, осуществляющей экспертную деятельность, но никак не к экспертам, главным принципом деятельности которых является независимость. Экспертная организация, существующая в любой предусмотренной законом фрорме, осуществляет полномочия, направленные на обеспечение в должном виде экспертной деятельности, создает условия для качественного выполнения работы экспертом. Именно поэтому фрорма организации не имеет значения для результата исследования.
} 
деятельности; 2.6 Правовые основы регламентации фрормальной и содержательной сторон результатов деятельности специалиста - консультации или заключения, а также особенности их использования в судопроизводстве и иных видах юрисдикционной деятельности; 2.7 Международно-правовое сотрудничество в области судебной экспертизы, экспертизы в иных видах юрисдикционной деятельности, а также участия специалиста в судопроизводстве и иных видах юрисдикционной деятельности.

3) Организационное обеспечение применения и использования специальных знаний в юрисдикционной деятельности: 3.1 Организация, структура, функции государственных и негосударственных судебно-экспертных организаций (далее - СЭО); 3.2 Информационное обеспечение СЭД; 3.3 Профессиональная деятельность, подготовка и повышение квалификации судебного эксперта, сертификация деятельности судебного эксперта, экспертная дидактика; 3.4 Психологические, логические и нравственные основы профессиональной деятельности судебного эксперта; профессиональная этика судебного эксперта.

4) Судебно-экспертные технологии: 4.1 Методология СЭД; 4.2 Процесс экспертного исследования и его стадии; 4.3 Судебно-экспертные методики, их типизация, стандартизация и паспортизация; 4.4 Профрилактическая деятельность эксперта и специалиста; 4.5 Профилактика экспертных ошибок.

Природа судебной экспертологии, как и опосредованно связь с другими науками, является сложной по своему составу, включая как юридическую составляющую, так и элементы, связи с другими (медициной, химией, физикой и т.д.) науками, что в очередной раз доказывает ее синтетический характер. Судебная экспертология как наука весьма тесно связана с другими отраслями научного знания, науками, прежде всего, с криминалистикой. Такая многогранная взаимосвязь подчеркивает характер судебной экспертологии. Криминалистика и судебная экспертология существуют как отдельные науки, но при этом находятся в тесной взаимосвязи, что обусловлено не только историческим развитием, но и методологией, задачами и целями.

\section{5. Объект судебной экспертологии.}

Предложенная выше структура требует уточнения объекта судебной экспертологии, поскольку его существование подтверждает самостоятельность и уникальность науки.

В качестве объекта общей теории судебной экспертизы выделялась сама «экспертная деятельность, рассматриваемая в качестве некоторой единой системы, включающей большое число компонентов (субъекты деятельности, объекты исследования, задачи, методы и т.п.)» [21]. Это мнение поддержали многие авторы [22- 24]. При этом некоторые ученые называют объектом судебной экспертологии только судебно-экспертную практику [20,24,25].

История развития судебной экспертологии свидетельствует о том, что для современного состояния науки общей теории судебной экспертизы оказывается недостаточно для дальнейшего развития и совершенствования научной мысли. Видоизменился и объект науки, если ранее объектом выступала государственная СЭД, то сейчас можно говорить о том, что СЭД претерпела качественные изменения, перестав характеризоваться признаком «государственной» принадлежности, что накладывает отпечаток на объект, особенно с учетом межгосударственного взаимодействия в рамках ЕАЭС. Кроме того, в структуре судебной экспертологии нами выделены положения о других формах использования специальных знаний, закономерности осуществления которых также включены в предмет данной науки, что не может не расширять ее объект. 
Многие ученые сходятся во мнении о том, что объектом судебной экспертологии является именно СЭД, однако по-разному подходят к основаниям выделения данного понятия в качестве объекта науки. Так, М.Я. Сегай выделяет четыре структурных блока, составляющих целостную систему СЭД: 1) деятельность государства по правовому обеспечению СЭД на законодательном и ведомственном нормативно-правовом уровнях; 2) деятельность государственных органов исполнительной власти, осуществляющих функцию управления СЭД; 3) деятельность главных субъектов СЭД, обеспечивающих организацию и проведение судебных экспертиз в государственных СЭО; 4) деятельность участников судопроизводства, причастных к проведению судебных экспертиз [20].

Полагаем что термин «СЭД» можно определить в широком и узком смысле. В узком смысле под судебно-экспертной деятельностью можно понимать только совокупность (систему) действий определенных субъектов (руководителей экспертных организаций, экспертов, специалистов), направленных на производство судебной экспертизы в судопроизводстве.

Комплексно СЭД можно представить как деятельность, включающую несколько компонентов: 1) совокупность (систему) действий определенных субъектов (руководителей экспертных организаций, экспертов в их взаимодействии с должностными лицами государственных органов, лицами, участвующими в судопроизводстве и ином юрисдикционном процессе), направленных на организацию и обеспечение производства, а также собственно производство экспертизы в различных видах юрисдикционной деятельности, включая судопроизводство; 2) организацию и функционирование СЭО; 3) профессиональную деятельность эксперта, его подготовку и повышение квалификации; 4) организацию и проведение научных исследований, информационное, в том числе методическое обеспечение судебной экспертизы; 5) международноправовое сотрудничество по указанным направлениям в области судебной экспертизы.

В определении СЭД можно выделить ряд черт, как общих, так и специфических. К общим можно отнести следующие: СЭД представляет собой комплекс разнообразных действий; совокупность этих действий имеет цель и задачи, собственный объект. Специфические признаки СЭД выражаются в: 1) ее комплексном характере, во взаимосвязи четырех составляющих: организация и функционирование СЭО, кадровое обеспечение (включая подготовку, повышение квалификации эксперта, сертификации его компетентности), научная (включая научно-методическое обеспечение) и экспертная (производство судебной экспертизы), а также международное сотрудничество по данным направлениям; 2) нормативной регламентации, несмотря на то, что в настоящее время она находится в процессе рефрормирования; 3) определенном субъектном составе, выполняющем соответствующее направление деятельности.

СЭД, таким образом, представляет собой урегулированный нормами права комплекс действий руководителей экспертных организаций, экспертов, специалистов во взаимодействии с участниками процесса, включающий производство судебной экспертизы, устройство и функционирование СЭО, кадровое обеспечение, организацию и проведение научных исследований, фрормирование научно-методического и информационного обеспечения, а также международное сотрудничество в области судебной экспертизы, основанный на унифицированном подходе к нормативной регламентации в государствах-членах ЕАЭС.

Экспертная деятельность, реализуемая в других видах юрисдикционной деятельности, за исключением судопроизводства, отличается от судебно-экспертной, помимо особенностей правового регулирования, субъектами, с которыми выстраивается взаимодействие экспертов, 
специалистов, руководителей СЭО. Например, в рамках таможенной или налоговой деятельности - это должностное лицо таможенного или налогового органа, осуществляющее контрольную деятельность, при осуществлении нотариальных действий по обеспечению доказательств - нотариус. Однако, полагаем такое отличие не существенным, поскольку оно не влияет на проведение экспертизы и сущность СЭД.

Помимо СЭД, объектом судебной экспертологии, как вытекает из предложенной структуры ее предмета, является деятельность специалиста в судопроизводстве или иной юрисдикционной деятельности, поскольку основы данной деятельности, ее общие закономерности разрабатываются судебной экспертологией, а именно - учением о формах применения и использования специальных знаний. Исходя из этого, объект судебной экспертологии является двухчастным, каждая из частей характеризуется общими закономерностями: 1) СЭД как комплекс действий, и 2) деятельность по применению и использованию специальных знаний в других формах в судопроизводстве или иных видах юрисдикционной деятельности.

Как уже отмечалось, деятельность по применению и использованию специальных знаний в других фрормах в судопроизводстве или иных видах юрисдикционной деятельности является объектом изучения не только судебной экспертологии. Судебная экспертология не изучает сугубо процессуальные аспекты реализации различных фрорм использования специальных знаний, это прерогатива процессуальных наук. Но результаты исследования сущности функционирования различных фрорм в указанных нами в предмете судебной экспертологии элементах, могут быть положены в основу обновления существующего противоречивого правового регулирования, унификации положений правового макроинститута «использование специальных знаний». Такое понимание объекта судебной экспертологии, с учетом деятельностного подхода, представляется, коррелирует с определением предмета науки судебной экспертологии.

Результаты.

Исследование позволило сформулировать отдельные выводы.

Определена наука, предметом исследования которой охватывается вся совокупность использования специальных знаний и предложена ее уточненная структура.

Поддерживая определение предмета судебной экспертологии, предложенное Е.Р. Россинской [26], считаем необходимым сформулировать его с учетом уточнения объекта исследования. Предметом судебной экспертологии являются теоретические, правовые и организационные закономерности осуществления СЭД в целом и деятельности по применению и использованию специальных знаний в других формах в судопроизводстве или иных видах юрисдикционной деятельности государств-членов ЕАЭС; закономерности возникновения, фрормирования и развития классов, родов и видов судебных экспертиз и их частных теорий на основе единой методологии, унифицированного понятийного аппарата и с учетом постоянного обновления и видоизменения судебно-экспертных знаний и разрабатываемые на основе познания этих закономерностей единые для всех видов судопроизводства и иных видов юрисдикционной деятельности унифицированные экспертные технологии, стандарты экспертных компетенций и сертифицированных экспертных лабораторий, единое правовое и организационное обеспечение СЭД и деятельности по применению и использованию специальных знаний в других формах в судопроизводстве или иных видах юрисдикционной деятельности государств-членов ЕАЭС. Исходя из предмета научного исследования, наука «судебная экспертология» представляет собой 
систему научных знаний об указанных закономерностях.

Объект судебной экспертологии является двухчастным, каждая из частей характеризуется общими закономерностями: 1) СЭД как комплекс действий, и 2) деятельность по применению и использованию специальных знаний в других фрормах в судопроизводстве или иных видах юрисдикционной деятельности.

\section{Заключение.}

Проведенный анализ позволяет утверждать, что судебная экспертология выступает обосновывающим знанием для нормативного регулирования и реализации правовых институтов судебной экспертизы, участия специалиста, а также экспертизы в иных видах юрисдикционной деятельности и ряда других, входящих в правовой макроинститут использования специальных знаний. Положения, выработанные судебной экспертологией, должны быть восприняты законодателем при осуществлении унификации межотраслевых правовых институтов, входящих в состав указанного макроинститута.

Интернациональность ученых, посвятивших свои труды разработкам основных положений судебной экспертологии, подчеркивает ее характер как науки, способной обеспечить концептуальное единство макроинститута использования специальных знаний и развитие основных их элементов применительно к любому виду судопроизводства или иной юрисдикционной деятельности.

\section{Список литературы}

1. Дьяконова О.Г. Судебная экспертиза и предварительные исследования как конкурирующие формы использования специальных знаний / О. Г. Дьяконова // Судебная экспертиза. 2019. № 2(58). C. 8-20. DOI 10.25724/VAMVD.GRST.

2. Зайцева Е.А. Концепция развития института судебной экспертизы: дис. ...д-ра юрид. наук. М., 2008. 437 c.

3. Дьяконова, О.Г. Специальные знания в судебной и иной юрисдикционной деятельности государств-членов ЕАЭС: теория и практика: дис. ...д-ра юрид.наук. Москва, 2021. В 2-х томах. $647 \mathrm{c}$.

4. Галяшина Е.И. Экспертология: проблемы наименования и предметная область знаний //Вестник экономической безопасности. 2016. № 4. С.25-28.

5. Россинская Е.Р. О предмете и системе теории судебной экспертизы - судебной экспертологии в современных условиях // Материалы 4-й межд. НПК «Теория и практика судебной экспертизы в современных условиях». М.: Проспект, 2013. С.3-10.

6. Россинская Е.Р. Современные представления о предмете и системе судебной экспертологии // Lex russica (Русский закон). 2013. T.95 № 4. С.421-428.

7. Кубицкий Ю.М. Пограничные вопросы судебной медицины и криминалистической экспертизы // Сборник трудов сотрудников бюро Главной судебно-медицинской экспертизы и кафедры судебной медицины Алма-Атинского мединститута. Алма-Ата, 1958. №2. С.9-18.

8. Винберг А.И.,Малаховская Н.Т. Судебнаяэкспертология. Общетеоретическиеи методологические проблемы судебных экспертиз: учеб. пособие / отв. ред. Б. А. Викторов. Волгоград: НИиРИО ВСШ МВД СССР, 1979. $182 \mathrm{c.}$

9. Белкин Р.С. Курс криминалистики: учеб. пособие для вузов. 3-е изд., дополненное. ЮНИТИДАНА, Закон и право, 2001. 837 с.

10. Шляхов А.Р. Предмет, метод и система советской науки криминалистической экспертизы // 
Вопросы криминалистики и судебной экспертизы. Алма-Ата, 1959. С.12-23.

11. Митричев С.П. Криминалистика и криминалистическая экспертиза // Социалистическая законность. 1966. № 5. С.13-15.

12. ВинбергА. И., Малаховская Н. Т. Судебная экспертология. Общетеоретические и методологические проблемы судебных экспертиз: учеб. пособие / отв. ред. Б. А. Викторов. Волгоград: НИиРИО ВСШ МВД СССР, 1979. 182 с.

13. Эйсман А. А. Экспертология в системе научного знания // Экспертные задачи и пути их решения в свете НТР. М., 1980. С.64-73.

14. Россинская Е.Р. Зарождение и формирование судебной экспертологии. В книге: Судебная экспертология: история и современность (научная школа, экспертная практика, компетентностный подход) / под ред. Е.Р. Россинской, Е.И. Галяшиной. М.: Проспект, 2017. 272 с.

15. Аверьянова Т.В. Судебная экспертиза: курс общей теории. М., 2006. 480 с

16. Россинская Е.Р. Генезис, система, функции, тенденции развития судебной экспертологии // Судебно-медицинская экспертиза. 2017. №5. C.4-7. DOI: 10.17116/sudmed20176054-7.

17. Зайцева Е.А. Реализация состязательных начал при применении специальных познаний в уголовном судопроизводстве: монография. Волгоград, 2006. 192 с.

18. Дьяконова О.Г. Понятие и структура предмета науки «судебная экспертология» // Вестник университета имени О.Е. Кутафина (МГЮА). 2015. № 12. С.86-99.

19. Дьяконова О.Г. Перспективы развития науки «Судебная экспертология» // Вестник экономической безопасности. 2016. № 4. С.38-45.

20. Сегай М.Я. Судебная экспертология: объект, предмет, природа и система науки // В зб. «Теорія та практика судової експертизи і криміналістики», Вип. 3. Харків: Право, 2003. С.25-32.

21. Аверьянова Т.В., Белкин Р.С., Корухов Ю.Г., Россинская Е.Р. Криминалистика: учебник для вузов /Т.В. Аверьянова, Р.С. Белкин, Ю.Г. Корухов, Е.Р. Россинская; под ред. Р.С. Белкина. М.: НормаИнфра* М., 1999. 600 с.

22. Белкин Р.С. Курс криминалистики: в 3-х томах. Т.2. М., 1997. 464 с.

23. Бикмаева Н.Л. Историко-криминалистические тенденции развития судебной экспертизы и судебных экспертных учреждений России, (XIX - конец XX века): автореф.дис... канд. юрид. наук. Нижний Новгород, 2006. 27 с.

24. Бычкова С.Ф. Становление и тенденции развития науки о судебной экспертизе. Алматы, 1994. $165 \mathrm{c}$.

25. Джавадов Ф.М. Экспертная деятельность и развитие науки о судебной экспертизе. Баку, 1998. $187 \mathrm{c}$.

26. Россинская Е.Р. Современная судебная экспертология - наука о судебной экспертизе и судебноэкспертной деятельности // Теория и практика судебной экспертизы. 2015. №4 (40). С.10-18.

\section{cUSกh4 9hStLheltrh 4hrunUUl UUUhl 9hsกhə3กhl

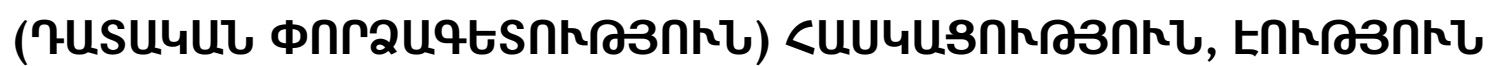 ty 4UחกRs4uס?}

\section{7.ulyninum 0.9.}

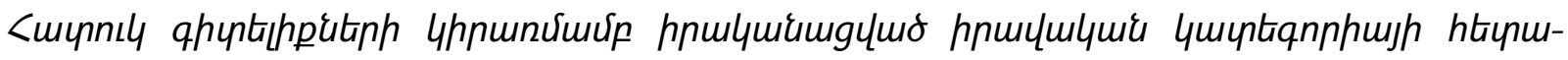

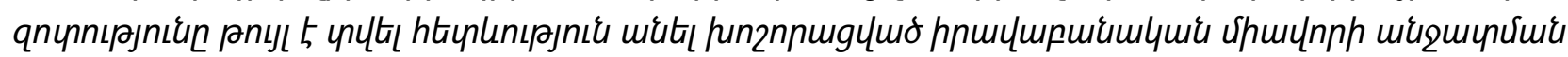

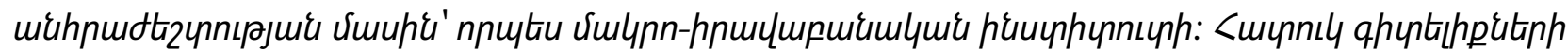

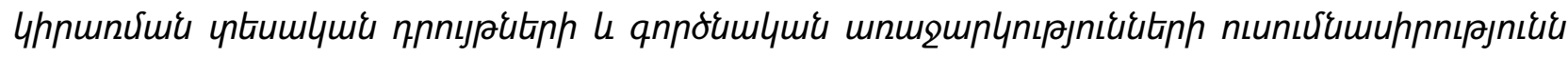

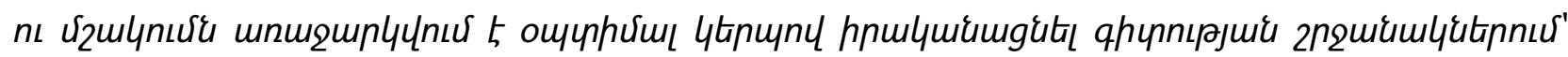




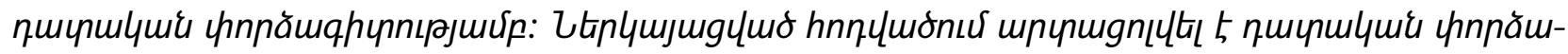

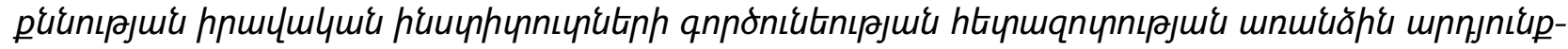

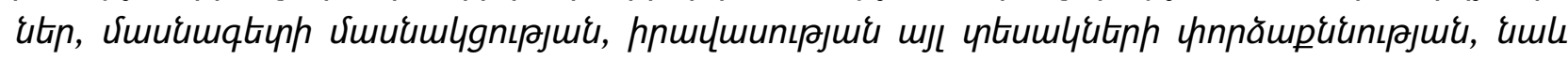

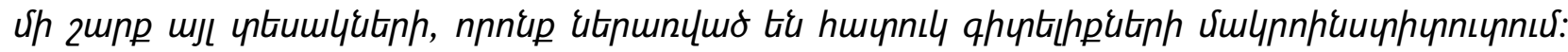

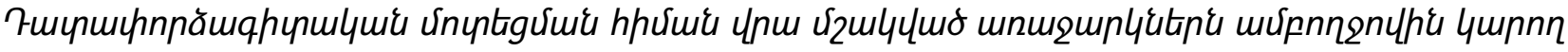

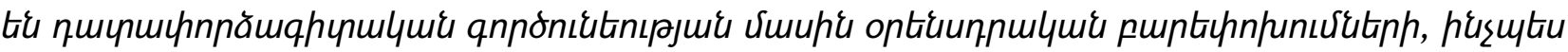

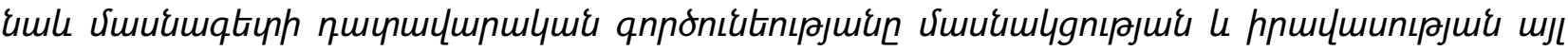

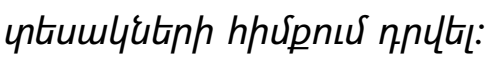

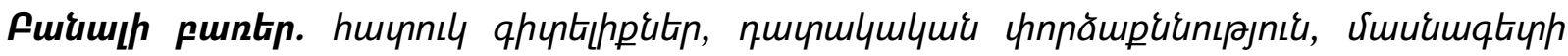

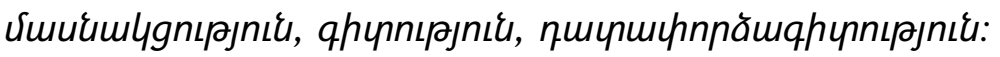

\section{THE SCIENCE OF USING SPECIAL KNOWLEDGE (FORENSIC EXPERTOLOGY): CONCEPT, ESSENCE, STRUCTURE}

\section{Dyakonova $O$.}

The conducted research of the legal category with the use of special knowledge made it possible to conclude on the necessity of separation of the large legal unit - macro-legal institution. The study and development of theoretical provisions and practical recommendations for the use of special knowledge is proposed to be optimally carried out within the framework of science - forensic expertology. The presented article reflects the individual results of a study on the implementation of legal institutions of forensic expertise, the participation of a specialist, as well as expertise in other types of jurisdictional activities and a number of others included in the legal macro-institution for the use of special knowledge. Proposals developed on the basis of an expert-based approach may well serve as the basis for reforming legislation on forensic expert activity and the participation of a specialist in legal proceedings and other types of jurisdictional activity.

Keywords: special knowledge, forensic expertiser, participation of a specialist, science, forensic expertology.

\section{Благодарности}

Автор выражает благодарность научному консультанту - Заслуженному деятелю науки Российской Федерации, доктору юридических наук, профессору Елене Рафаиловне Россинской - за профессиональные советы и неоценимую поддержку в процессе научного исследования и подготовки работы на соискание ученой степени.

Автор также благодарит за проявленное внимание к научному исследованию и представление официальных отзывов на него заведующего кафедрой судебных экспертиз и криминалистики Российского государственного университета правосудия д.ю.н., профессора Т.Ф. Моисееву, заместителя директора Российского фредерального центра судебной экспертизы при Министерстве юстиции Российской Федерации д.ю.н., доцента Г.Г. Омельянюка, декана факультета подготовки криминалистов Московской академии следственного комитета д.ю.н., доцента О.Ю. Антонова, “Национальное бюро экспертиз” Национальной академии наук Республики Армения в лице директора канд.мед.наук А.Н. Овсепяна и заместителя директора канд. хим.наук П.С. Восканяна, кафедру криминалистики юридического факультета Белорусского 
государственного университета в лице заведующего кафедрой д.ю.н., профессора В.Б. Шабанова и доцента кафедры к.ю.н., доцента В.Л. Григоровича, профессора Казахского национального университета имени аль-Фараби д.ю.Н., профессора К.Н. Шакирова, кафедру криминалистики Института права Башкирского государственного университета в лице заведующего кафедрой д.ю.н., профессора И.А. Макаренко и профессора кафедры д.ю.н., профессора Ф.Г. Аминева, профессора Волгоградской академии МВД России д.ю.н., профессора Е.А. Зайцеву и профессора Владимирского юридического института Федеральной службы исполнения наказаний д.ю.н., профрессора Л.В. Лазареву.

\section{Acknowledgements}

The author expresses gratitude to the scientific consultant - Honored Scientist of the Russian Federation, Doctor of Science (Law), Professor Elena Rafailovna Rossinskaya - for professional advice and invaluable support in the process of scientific research and preparation of work for a degree.

The author also gratitude for the attention to the scientific research and the presentation of official reviews on it the Head of the Department of Forensic Examinations and Criminalistics щa Russian State University of Justice Doctor of Science (Law), Professor Tatiana F. Moiseeva, the Deputy Director of the Russian Federal Center for Forensic Expertise under the Ministry of Justice of the Russian Federation Doctor of Science (Law), Docent Georgy G. Omelyanyuk, the Dean of the Faculty of Training Criminalists of the Moscow Academy of the Investigative Committee Doctor of Science (Law), Docent Oleg Yu. Antonov, "National Bureau of Expertise" of the National Academy of Sciences of the Republic of Armenia represented by Director Candidate of Science (Medical) Argam N. Hovsepyan and Deputy Director Candidate of Science (Chemistry) Patvakan S. Voskanyan, the Department of Criminalistics of the Law Faculty of the Belarusian State University represented by the head of the department Doctor of Science (Law), Professor Vyacheslav B. Shabanov and associate professor of the department Vasiliy L. Grigorovich, Professor of the Al-Farabi Kazakh National University Doctor of Science (Law), Professor Karimzhan N. Shakirov, the Department of Criminalistics of the Institute of Law of the Bashkir State University represented by the head of the department Doctor of Science (Law), Professor Ilona A. Makarenko and professors of the department Doctor of Science (Law), Professor Farit G. Aminev, Professor of the Volgograd Academy of the Ministry of Internal Affairs of Russia Doctor of Science (Law), Professor Elena A. Zaitseva and Professor of the Vladimir Law Institute of the Federal Penitentiary Service Doctor of Science (Law), Professor Larisa V. Lazareva. 